\title{
The prevalence of renewable energy in the Russian energy market
}

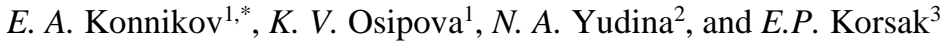 \\ ${ }^{1}$ Peter the Great St. Petersburg Polytechnic University, Saint-Petersburg, Russia \\ ${ }^{2}$ Kazan State Power Engineering University, Kazan, Russia \\ ${ }^{3}$ Belarussian National Technical University, Minsk, Republic of Belarus
}

\begin{abstract}
The energy crisis of 1973-1974 showed that it is difficult to constantly increase the power supply of production, based only on traditional energy sources. The power supply of society is the basis of its scientific and technological progress. It means that it is necessary to introduce unconventional, alternative energy sources more widely. Unlike fossil fuels, unconventional forms of energy are not limited to geologically reserves. Their use and consumption does not lead to the inevitable exhaustion of stocks. However, currently, the reform of world energy markets and increasing the share of renewable energy sources in their structure is a long and innovative process. Lots of countries (Russia in particular) bear significant risks because of reforming their own energy market, which causes a slight increase in the share of renewable energy sources. In this regard, the purpose of this study is to analyse the influence of environmental factors on the development of renewable energy sources in Russia. The result of this study is a system of econometric equations, which allows to evaluate the impact of changes in key drivers of the development of the renewable energy market.
\end{abstract}

\section{Introduction}

The energy sector requires new approaches to its arrangement due to the increased requirements for the environmental protection. The main factor in assessing the feasibility of using renewable energy (RE) is the cost of produced energy in comparison with the cost of energy produced by traditional sources. Non-traditional sources are particularly important to supply local energy consumers.

The aim of this article is to analyse the influence of factors of the renewable energy development and to identify the prospects for the development of this industry in Russia.

The object of the research is the renewable energy market. The subject of the research is the prevalence of renewable energy in the Russian Federation.

Despite the widespread opinion about the high cost of electricity produced at RE facilities, the energy produced at nuclear power plants is one of the most expensive. The average payback period for capital investments in traditional power plants is $8-10$ years. The payback period for various renewable energy projects in Russia is from 3 to 5 years [1-24].

The future of the Russian renewable energy largely depends on the model of regulation of its development. This requires an understanding not only in terms of technical problems of energy supply, but also in the context of social development goals of the country.
RE technologies are still more cost-effective and uncompetitive than traditional power generation technologies. The widespread introduction of renewable energy sources requires taking into account all the components of their efficiency concept: energy, environmental, regime (operational), economic and social efficiency. The energy payback period for groundbased wind and photovoltaic power plants takes into account the energy consumption for the production of materials, equipment, transportation, installation, disposal and own needs. The analysis of payback periods shows that during 25 years of service, the wind turbine produces the electric energy $32.3-50.4$ times more than it spent on its entire life cycle. The analysis of greenhouse gas emission data from the USA fuel energy industry and Russian fuel power plants showed that harmful emissions from photovoltaic stations are 35-100 times less than for coal plants. Harmful emissions from wind power plants are two orders of magnitude less than from thermal ones. The experience of foreign wind power plants operation confirms the possibility of accurate forecasting of electricity generation for different periods. It can be the basis for solving the issues of the need for the reservation, regulation of active and reactive power, as well as the need for various resources in the operation of a wind power plant. Hydroelectric power plants are the most economical renewable sources of electrical energy. The assessment of the social effect of renewable energy sources development shows the dynamics of creating additional jobs in the field of

\footnotetext{
*Corresponding author konnikov.evgeniy@gmail.com
} 
equipment production and operation of renewable energy facilities, improving the population's standard of living, the development of local infrastructure and industry. The analysis of RE development shows that large oil and gas companies began to develop renewable energy sources. Given the instability in the oil market, experts conclude that the leading positions will be fixed for energy holdings oriented to the RE.

The Russian Federation is making efforts to create and implement legislative regulation of RE. At the same time, the rapid development of renewable energy in the world energy market can undermine the position of the Russian oil and gas industry.

According to experts, Russia has great potential not only in the market of traditional energy sources, but also in the market of renewable energy sources.

\section{Methodology}

To analyse the prevalence of renewable energy in Russia the volume of $\mathrm{RE}$ production will be taken as an endogenous variable (Y1).

Exogenous factors for this variable are [25-30]:

- $\mathrm{x}_{1}-$ GDP per capita at purchasing power parity. It determines the level of economic development and growth. Accordingly, the higher the level of economic development, the more the state is concerned about the issue of renewable energy.

- $\mathrm{x}_{2}$ - the prevalence of the Internet (million people). The more people are informed, the more they are interested in preservation of the environment.

- $\mathrm{x}_{3}$ - the fertility rate. The fertility affects the production of electricity. The more people, the greater the energy consumption.

- $\mathrm{x}_{4}$ - investments in the fixed capital (million rubbles). This is the cost directed to the creation and reproduction of fixed assets. The more investments are made in the development; the more energy is produced.

- $\mathrm{x}_{5}$ - investments in the electricity sector (billions of rubbles). Increasing the share of investments in the electricity sector contributes to the development of RE.

- $\mathrm{x}_{6}$ - the oil price per barrel (USD). Increasing the price of oil affects the use of renewable energy as an alternative to expensive fuel.

The second endogenous variable describing the state of RE in Russia (Y2) is the volume of RE market in Russia.

Exogenous factors for this variable are [25-30]:

- $\mathrm{z}_{1}$ - the population mortality rate. The increase in mortality affects the reduction of domestic demand. It affects the volume of renewable energy market in Russia.

- $\mathrm{z}_{2}$ - GDP per capita at purchasing power parity. It affects the volume of sales in the res market.

- $\mathrm{z}_{3}$ - the fertility rate. Fertility affects power generation. The more people, the more energy consumption, therefore, the more sales.

- $\mathrm{z}_{4}$ - the unemployment rate. The higher the unemployment rate, the lower the sales.

- $\mathrm{z}_{5}$ - investments in the electricity sector (billions of rubbles). Increasing the share of investments in the electricity sector contributes to the development of RE and increase market volumes.

- $\mathrm{z}_{6}$ - the oil price per barrel (USD). The increase in the price of oil affects the use of renewable energy as an alternative to expensive fuel, which accordingly increases sales.

- $\mathrm{Z}_{7}$ - the price of natural gas. The increase in the price of natural gas affects the use of renewable energy as an alternative to expensive fuel, which accordingly increases sales.

The next step is the regression analysis in the following sequence [25-35]:

- Checking endogenous variable for the time dependence in order to exclude a temporary trend (if one exists) or to enable the background factor as exogenous.

- Checking the exogenous variables for multicollinearity.

- Performing the regression analysis based on the remaining factors. Exclude factors with a p-value of more than $10 \%$, i.e. the probability of error in the deviation from the null hypothesis exceeds $10 \%$. Then perform the regression analysis again.

- Checking the significance of the obtained coefficients by student's criterion (based on t-statistics). If $\mid \mathrm{t}$ calculated $\mid \geq \mathrm{t}$ tabular, then the obtained coefficients of the equation are significant, i.e. the sample corresponds to the general population.

- Checking the significance of the model based on Fisher's F-test and coefficient of determination. If Fcalculated $\geq$ Ftabular, then the model is significant, i.e. the sample corresponds to the general population. The closer the coefficient of determination (the coefficient of determination adjusted for sample size) to 1 , the more accurate the model. The coefficient must be at least 0.7 .

- The residual analysis.

- Calculating of the average approximation error.

- Assessing the current state and influence of exogenous factors with the highest elasticity coefficients on the resulting variable.

\section{The results}

Firstly, the correlation of exogenous with endogenous variables was analysed in order to determine the existence of a relationship between them. The obtained correlation coefficients show a high direct correlation between the prevalence of the Internet and the volume of RE production $(\mathrm{r}=0.9)$.

Then the multiple regression was performed. The coefficient of determination is 0.99 . But it is necessary to pay attention to the values of $p$-level. If $p$-value $>0.05$, this exogenous value should be excluded from the analysis. $\mathrm{x}_{1}, \mathrm{x}_{2}, \mathrm{x}_{3}$ should be excluded from the analysis.

$\mathrm{x}_{4} ; \mathrm{x}_{5}$ and $\mathrm{x}_{6}$ will be used as exogenous factors for the first endogenous variable (Y1).

All variables were tested for significance by Student's t-test. Its value is 2.09 . According to the condition, the coefficient is considered significant if $t_{\text {calculated }} \geq t_{\text {tabular }}$. Regarding all these variables, the p-level value did not exceed 0.05, which satisfies the requirements of the analysis. The coefficient of determination (R2) for this 
equation is 0.978 . It proves the reliability of the constructed model.

It can be confirmed graphically by the ratio of the actual and theoretical indicators on the chart.

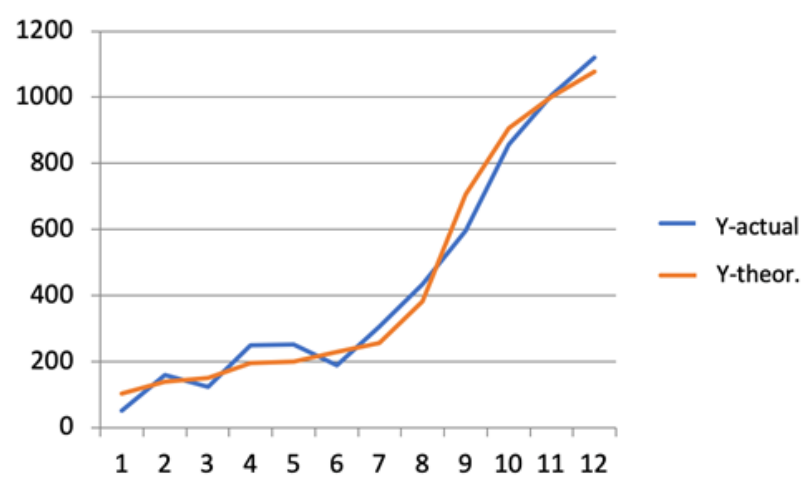

Fig. 1. Indicators of $\mathrm{Y}$-actual and $\mathrm{Y}$-theoretical.

The approximation error is $18 \%$. It is less than $20 \%$, what indicates the accuracy of the proposed model.

Also, the confidence intervals were calculated for the endogenous indicator (Figure 2). It shows what the maximum/minimum value the indicator can take in a given period of time.

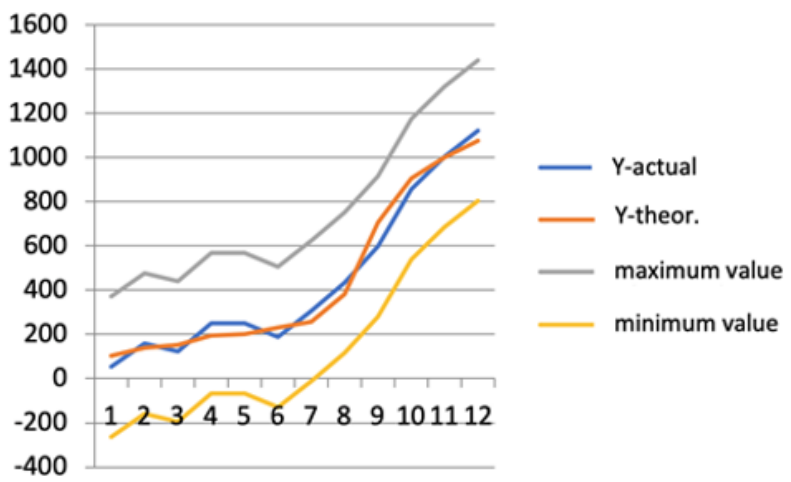

Fig. 2. Indicators of $\mathrm{Y}$-actual and $\mathrm{Y}$-theoretical (maximum/minimum value).

Also, the elasticity coefficients were calculated. It shows how many percent the endogenous index (Y) changes, if one of the exogenous indicators $(\mathrm{X})$ changes by $1 \%$.

Table 1. Elasticity coefficients.

\begin{tabular}{|c|c|c|}
\hline $\begin{array}{c}\text { Investments in the } \\
\text { fixed capital } \\
\text { (million rubbles) }\end{array}$ & $\begin{array}{c}\text { Investments in the } \\
\text { electricity sector } \\
\text { (billions of rubbles) }\end{array}$ & $\begin{array}{c}\text { The oil price } \\
\text { per barrel } \\
\text { (USD) }\end{array}$ \\
\hline $4.5 \mathrm{E}-09$ & -0.23466 & -27.6972 \\
\hline
\end{tabular}

The final regression model:

$$
Y_{1}=-6.109+0.0001 \cdot X_{4}-0.45 \cdot X_{5}-5.133 \cdot X_{6}
$$

Then the second equation was analysed. The correlation of exogenous with endogenous variables was analysed in order to determine the existence of a relationship between them. The obtained correlation coefficients show a high direct correlation between GDP per capita and sales volume $(\mathrm{r}=0.89)$

Then the multiple regression was performed. The coefficient of determination is 0.97 . But it is necessary to pay attention to the values of $\mathrm{p}$-level. If $\mathrm{p}$-value $>0.05$, this exogenous value should be excluded from the analysis. $\mathrm{Z}_{1}, \mathrm{Z}_{4}, \mathrm{Z}_{5}, \mathrm{Z}_{7}$ should be excluded from the analysis.

$\mathrm{z}_{2} ; \mathrm{z}_{3}$ and $\mathrm{z} 6$ will be used as exogenous factors for the first endogenous variable $\left(\mathrm{Y}_{2}\right)$.

All variables were tested for significance by Student's t-test. Its value is 2.09 . Regarding all these variables, the p-level value did not exceed 0.05 , what satisfies the requirements of the analysis. The coefficient of determination $\left(R_{2}\right)$ for this equation is 0.97 . It proves the reliability of the constructed model.

It can be confirmed graphically by the ratio of the actual and theoretical indicators on the chart.

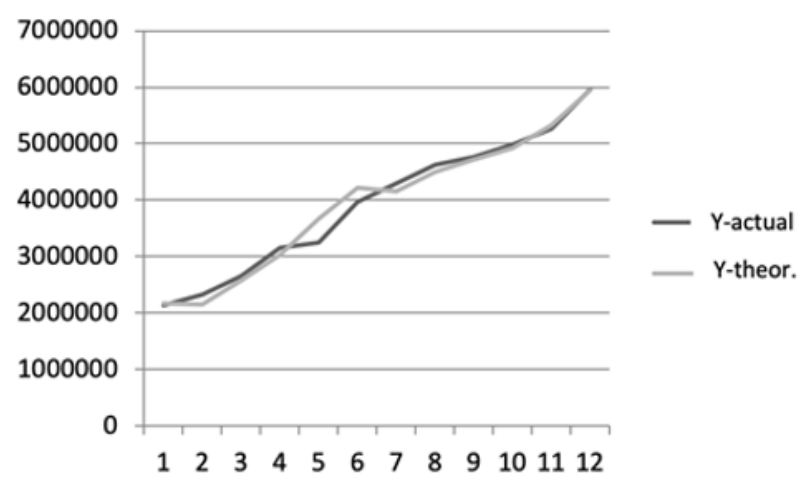

Fig. 3. Indicators of Y-actual and Y-theoretical.

The approximation error is $2 \%$. It is less than $20 \%$, what indicates the accuracy of the proposed model.

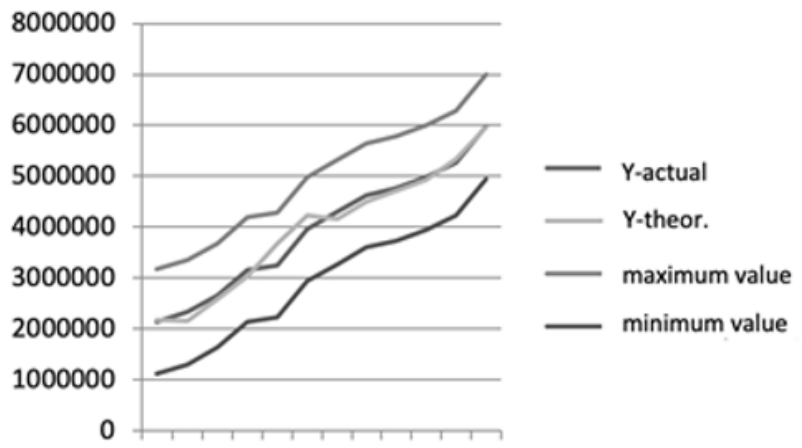

123456789101112

Fig. 4. Indicators of $\mathrm{Y}$-actual and $\mathrm{Y}$-theoretical (maximum/minimum value).

Also, the confidence intervals for the endogenous indicator and the elasticity coefficients were calculated.

Table 2. Elasticity coefficients.

\begin{tabular}{|c|c|c|}
\hline $\begin{array}{c}\text { GDP per capita at } \\
\text { purchasing power } \\
\text { parity }\end{array}$ & The fertility rate & $\begin{array}{c}\text { The oil price } \\
\text { per barrel } \\
\text { (USD) }\end{array}$ \\
\hline 6.932 & -5.071 & -8.7 \\
\hline
\end{tabular}


The final regression model:

$$
\begin{aligned}
& Y_{2}=1314811.577+367.95 \cdot Z_{2}- \\
& -2.29 \cdot Z_{3}-18588.72 \cdot Z_{6}
\end{aligned}
$$

The general system of equations derived by the study:

$$
\left\{\begin{array}{l}
Y_{1}=-6.109+0.0001 \cdot X_{4}-0.45 \cdot X_{5}-5.133 \cdot X_{6} \\
Y_{2}=1314811.577+367.95 \cdot Z_{2}- \\
-2.29 \cdot Z_{3}-18588.72 \cdot Z_{6}
\end{array}\right.
$$

\section{Conclusion}

It is important to expand the use of renewable energy in the Russian Federation. It should be a priority direction in the implementation of the state policy in the field of:

- energy efficiency of production;

- diversification of energy supply to energy-deficient areas;

- development of the national industry;

- creation of additional jobs;

- implementation of the existing high scientific and technical potential of Russia;

- environmental improvements in a number of Russian regions;

- compliance with international greenhouse gas emission reduction obligations.

The analysis of the econometric model revealed that the volume of renewable energy production is influenced by the volume of investments in the fixed capital, investments in the electricity industry, the oil price. And the volume of RE sales is influenced by GDP per capita, the oil price and fertility rate. The growth of the economy increases a demand. In our case, it affects the volume of sales in the RE market. It can be concluded that in the Russian Federation there are prospects for both economic and social development of renewable energy.

\section{References}

[1] N. Afanasieva, D. Rodionov, and Y. Vasilev, System of indicators of coal enterprise competitiveness assessment 39(36), (2018)

[2] R. Aliev, and K. Zaharcheva, Background and comparative analysis of the development of renewable energy by oil and gas companies (Bulletin of Eurasian science https://esj.today/PDF/46ECVN318.pdf) (2018)

[3] P. Bezrukih, The effectiveness of renewable energy (Myths and facts Energy: Economics, Technique, Ecology) 11-24 (2015)

[4] P. Bućko, Renewable Energy Sources on the Polish Electrical Energy (Market Acta Energetica) 19, 40-46 (2014)

[5] T. Bugaeva, A. Khabarov, O. Novikova, and U. Plotkina, Development and testing of the genetic algorithm to select a scenario of distributed generation power supply system (IOP Conference Series: Materials Science and Engineering) 497, (2019)

[6] I. Grechuhina, and P. Kiryushin, Renewable energy as a factor in pricing in the electricity market Bull. of university (State university of management) 120 (2014)

[7] S. Gutman, I. Zaychenko, and E. Rytova, Development strategy of Far North transport infrastructure: Problems and prospects (Proceedings of the 29th International Business Information Management Association Conference - Education Excellence and Innovation Management through Vision 2020: From Regional Development Sustainability to Global Economic Growth) 1439-1449 (2017)

[8] S. Gutman, A. Kozlov, and A. Teslya, Sustainable development of industrial enterprises in oneindustry towns through harmonization of main stakeholders' interests: Case of Russian arctic zone (Proceedings of the $31 \mathrm{st}$ International Business Information Management Association Conference) 3014-3023 (2018)

[9] L. Junfeng, M. Lingjuan, W. Zhongying, and F. Jingchun, Renewable Energy Markets and Policies in China (doi 10.1007/978-3-540-75997-3 22) (2008)

[10] P. Kiryushin, GREEN ECONEMY: Opportunities and Constraints for Russian companies (IFRI) 24 (2014)

[11] O. Korobova, Prospects of renewable energy in Russia Mining information and analytical Bulletin (scientific and technical magazine) 175-188 (2009)

[12] T. Lan'shina, and V. Barinova, Global renewable energy governance: international trends (Russia Bulletin of international organizations: education, science, new economy) 110-26 (2017)

[13] U. Leprich, P. Hoffmann, and M. Luxenburger, Certificates in Germany's Renewable Energy Market (doi: 10.1007/978-3-319-46427-5_7) (2017)

[14] V. Makarov, O. Novikova, and A. Tabakova, Energy efficiency in "Green construction": Experience, issues, trends (6th International Conference on Reliability, Infocom Technologies and Optimization (Trends and Future Directions) (ICRITO) 698-703 (2017)

[15] M. Kaltschmitt, Renewable Energy Renewable Energy from Biomass renewable energy from Biomass (Introduction, doi: 10.1007/978-1-4419-08513 924) (2012)

[16] Y. Nazarova, and O. Goryunov, Socioeconomic effects of renewable energy development in Russia Industrial power engineering 46-53

[17] L. Nikolova, D. Rodionov, and A. Litvinenko, Sustainability of the business in the conditions of globalization (Proceedings of the 30th International Business Information Management Association Conference, IBIMA 2017 - Vision 2020: Sustainable Economic development, Innovation Management, and Global Growth) 417-421 (2017)

[18] O. Novikova, S. Shirokova, A. Tabakova, and A. Shadrin, University energy management improvement on basis of standards and digital 
technologies (MATEC Web of Conferences doi: 170. 03006. 10.1051/matecconf/201817003006) (2018)

[19] B. Porfir'ev, and S. Roginko, Alternative energy and socially oriented economy Bull. of St. Petersburg University (Economy 3 doi: https://doi.org/10.21638/11701/spbu05.2016.301) (2016)

[20] A. Rubino, Renewable energy: Market integration in Germany Nature Energy, 1, (2016)

[21] V. Shestakov, O. Novikova, A. Melnichenko, and A. Luchnikova, Methodical approaches to energy supply with usage of renewable energy sources on objects of transport infrastructure of federal importance MATEC Web of Conferences, 245, (2018)

[22] A. Sidorov, The use of renewable energy sources as a means of achieving sustainable development of Russia (2015)

[23] N. Strahova, and P. Lebedinskij, Analysis of energy efficiency of the Russian economy (Engineering Bulletin of the Don 3) (2012)

[24] N. Teodorovich, and G. Isaeva, Alternative energy: prospects of development (Internet-journal Science of science) (2016)

[25] C. Coons, Renewing energy markets [8] (Economist: United Kingdom) 413 (2017)

[26] G. Dvas, and Y. Dubolazova, Development and business support of innovative enterprises in the Russian Federation (Proceedings of the 31st International Business Information Management Association Conference, IBIMA 2018: Innovation Management and Education Excellence through Vision 2020) 5654-5657 (2018)

[27] V. Germanovich, and A. Turilin, Alternative energy sources and energy saving (St. Petersburg Publ. house Science and Technology) 8-10 (2014)

[28] I. Grechuhina, Factors of development of renewable energy sources in Russia and in the world Research and development in the era of globalization (Sat. articles international. science-prakt. conf. Scientific publishing center «Aeterna»: Ufa) 75-79 (2016)

[29] O. Kichigin, O. Nadezhina, V. Degtereva, and D. Ovsyanko, The concept of participation of fuelenergy companies in development of regional socioeconomic systems (Proceedings of the 32nd International Business Information Management Association Conference) 6837-6842 (2018)

[30] S. Niyazova, J. Kuporov, and O. Nadezhina, Development of an adaptive management model for innovative activities of an enterprise (Proceedings of the 28th International Business Information Management Association Conference - Vision 2020: Innovation Management, Development Sustainability, and Competitive Economic Growth) 2210-2222 (2016)

[31] F. Liliyana, A. Svirina, O. Polina, D. Garanin, N. Lukashevich, and V. Leventsov, TechnoMOOC development of the basis of remote lab access (Proceedings of the International Conference Quality Management, Transport and Information Security, Information Technologies) 680-684 (2017)

[32] I. Rudskaya, and D. Rodionov, Comprehensive evaluation of Russian regional innovation system performance using a two-stage econometric model 39(4), (2018)
[33] T. Shabunina, S. Shchelkina, and D. Rodionov, An innovative approach to the transformation of eco-economic space of a region based on the green economy principles (Academy of Strategic Management Journal, 16(1), 176-185 (2017)

[34] E. Sharafanova, Y. Fedosenko, and A. Skhvediani, Regional Labor Market: Forecasting the Economic Effect of Cooperation between Universities and Entrepreneurs (Journal of Advanced Research in Law and Economics 8, 1908-1915 (2017)

[35] A. Sokolitsyn, M. Ivanov, and N. Sokolitsyna, Statistic modeling industrial enterprises production process parameters (Proceedings of the 30th Inter-national Business Information Management Association Conference, IBIMA 2017 - Vision 2020: Sustainable Economic development, Innovation Management, and Global Growth) 1041-1052 (2017) 